\title{
Pengaruh Reproduksi Ruang terhadap Perubahan Sosial dan Ekonomi di Kelurahan Samata Kabupaten Gowa
}

\author{
The Impact of Reproduction Space to \\ Social and Economy in Samata Gowa Regency \\ Nur Rahmi Aulia*, Nur Syam AS \& Fadhil Surur
}

Jurusan Teknik Perencanaan Wilayah dan Kota, Fakultas Sains dan Teknologi, Universitas Islam Negeri Alauddin Makassar, Indonesia

Diterima: Agustus 2019; Disetujui: Desember 2019; Dipublish: Desember 2019

*Coresponding Email: fadhil.surur@uin-alauddin.ac.id

\begin{abstract}
Abstrak
Kelurahan Samata terletak di Kabupaten Gowa, munculnya kawasan-kawasan baru pada Kelurahan Samata mendorong perubahan pemanfaatan lahan yang awalnya ditempati masyarakat setempat untuk diubah menjadi area perumahan skala menengah ke atas. Proses rehabilitasi dan urban renewal dimaknai sebagai gentrifikasi yang akan dikuasai oleh para pemilik modal untuk dikembangkan menjadi real estate. Penelitian ini bertujuan untuk mengetahui kondisi umum lokasi penelitian, mengidentifikasi proses reproduksi ruang dan pengaruhnya terhadap kondisi sosial dan ekonomi masyarakat. Metode analisis yang digunakan adalah analisis superimpose dan analisis deskriptif. Berdasarkan analisis diperoleh bahwa dengan adanya reproduksi ruang pembangunan fasilitas perekonomian dan permukiman yang berdampak pada nilai tinggi sehingga banyak masyarakat yang menjual lahannya. Perubahan kondisi sosial dan ekonomi masyarakat menurut analisis korelasi yaitu pengaruh perkembangan Kelurahan Samata memberikaan pengaruh besar terhadap pertambahan penduduk dengan nilai korelasi 0,98 dengan pengaruh sangat kuat dan perkembangan pekerjaan dengan nilai korelasi 0,80 dengan pengaruh sangat kuat. Jadi pengaruh reproduksi ruang di Kelurahan Samata memberikan dampak besar terhadap pekembangan ruang fisik yang ada di Kelurahan Samata.
\end{abstract}

Kata Kunci: Reproduksi Ruang, Perubahan Sosial, Perubahan Ekonomi

\begin{abstract}
Samata Urban Village is located in Gowa Regency, the emergence of new areas in the Samata Urban Village replaces the land that was originally occupied by the local community to be transformed into an elite and luxurious area, both that occurred in the city center and in the periphery. The process of rehabilitation and urban renewal is what is referred to as gentrification which in the end urban spaces are utilized by those with high income into real estate. This study aims to identify general condition, to determine the reproduction of space and the impact to social and economic. The analytical method used is superimpose analysis and descriptive analysis. Based on the analysis it was found that with the reproduction of space for the construction of economic and residential facilities that have a high value impact, so many people sell their land. Changes in social and economic conditions according to the correlation analysis of the influence of the development of the Village Samata gave a large influence on population growth with a correlation value of 0.98 with a very strong influence and job development with a correlation value of 0.80 with a very strong influence. So the influence of spatial reproduction in Samata Village has a big impact on the development of physical space in the Samata Village.
\end{abstract}

Keywords: Space Repdorduction, Social, Economy

How to Cite: Aulia, N.R, Nur Rahmi Aulia*, Syam, A.S.N. \& Surur, F. (2019). Pengaruh Reproduksi Ruang terhadap Perubahan Sosial dan Ekonomi di Kelurahan Samata Kabupaten Gowa. Journal of Education, Humaniora and Social Sciences (JEHSS). 2 (2): 237-244. 
Nur Rahmi Aulia, Nur Syam AS \& Fadhil Surur, Pengaruh Reproduksi Ruang terhadap

\section{PENDAHULUAN}

Peningkatan jumlah penduduk pada beberapa kota metropolitan di Indonesia merupakan manifestasi dari peningkatan terhadap kebutuhan untuk permukiman (Diningrat, 2015). Menurut Sujarto (1995), terdapat tiga strategi yang dilakukan dalam rangka menghadapi permasalahan tersebut yaitu intensifikasi perkotaan, eksetensifikasi kawasan kota dan rencana pembangunan kota sebagai pusat pertumbuhan baru. Sehingga pilihan strategi pembangunan kota baru dinilai sebagai strategi terbaik dalam menghadapi permasalahan lahan di perkotaan selain itu dapat mendorong optimalisasi aktivitas permukiman (Diningrat, 2015).

Proses perkembangan perkotaan berdampak pada terjadinya konversi lahan dalam volume besar yang awalnya kawasan pertanian, berubah menjadi kegiatan bukan pertanian. Konversi lahan berpengaruh signifikan terutama pada daerah peri urban, hal ini akan terus terjadi jika tidak dikontrol dengan kebijakan pemerintah. Kehadiran masyarakat pendatang pada daerah tersebut menimbulan permasalahan baru yaitu fenomena kelas bawah tinggal bersama warga setempat dalam satu kawasan permukiman, dan masyarakat kelas atas yang tinggal di kawasan elit, menimbulkan pengaruh pada perubahan sistem sosial masyarakat di wilayah tersebut. Hal inilah yang disebut dengan segregasi sosial. Masyarakat dikelompokkan oleh etnis, ideologi dan kepentingan dalam suatu kelompok organisasi sosial.

Fenomena segregasi yang muncul adalah pada era post modern telah terbangun pusat ekonomi berbasis teknologi tinggi dan munculnya komunitas berpagar (gated communities) diantara kemiskinan perkotaan. Hal ini menunjukkan kesenjangan dan perbedaan yang sangat mencolok antara ruang perkotaan yang kaya dan ruang perkotaan yang miskin. Di sinilah terjadi segregasi secara spasial. Fenomena munculnya kawasan-kawasan baru pada Kelurahan Samata menggantikan lahan yang semula ditempati masyarakat setempat untuk diubah menjadi kawasan elit dan mewah, baik yang terjadi di pusat kota maupun di kawasan pinggiran.

Proses perkembangan kota ini identik dengan gentrifikasi dimana ruang perkotaan akan dimanfaatkan oleh para pemilik modal dengan penghasilan yang tinggi sebagai lahan real estate. Hal ini mencirikan fragmentasi kota, yang tidak lepas dari konsep segregasi baik ekonomi, maupun sosial budaya. Hal itu dapat diartikan sebagai penciptaan pembagian spasial (spatial divide) menjadi beberapa organisasi masyarakat. 
Fenomena ini dapat dibuktikan secara logis dengan menjamurnya bangunan mewah yang sangat tertutup, penataan rapi dan kualitas pengamanan yang baik berdampingan dengan permukiman masyarakat yang kumuh dengan segala keterbatasan sarana dan prasarana yang dimiliki. Kawasan elit tersebut hanya terdiri dari satu gerbang inti yang dijaga secara ketat kemudian membatasi orang - orang yang akan masuk pada kawasan tersebut. Selanjutnya kawasan elit ini terlayani dengan infrastruktur khusus bagi masyarakat setempat, antara lain pusat perbelanjaan, taman, restoran, lapangan olahraga, sarana kesehatan dan lainnya. Hal ini berbanding terbalik dengan penyediaan infrastruktur pada kawasan kumuh.

Hal inilah yang menyebabkan adanya segregasi penduduk pada wilayah Kelurahan Samata seperti perubahan lanskap, perubahan ruang, perubahan tata guna lahan. Bahkan lebih dari itu, wilayah Kelurahan Samata sekarang telah berubah dengan sangat cepat baik dari sisi ruang (space), populasi, kondisi demografis dan bahkan hubunganhubungan interaksi sosial yang kian kompleks akibat adanya perumahan-perumahan baru di sekitar perkampungan lama warga desa atau di atas lahan-lahan pertanian. Maka dari itu penelitian ini mengkaji tentang pola segregasi permukiman yang mempunyai hubungan yang erat terhadap pola perubahan segregasi penduduk yang ada di Kelurahan Samata.

\section{METODE PENELITIAN}

Jenis penelitian ini merupakan penelitian non-eksperimental dan bersifat deskriptif kuantitatif, yaitu penelitian yang mendeskripsikan data apa adanya dan menjelaskan data atau kejadian dengan kalimat-kalimat penjelasan secara kualitatif. Penelitian ini dilaksanakan di Kelurahan Samata, Kecamatan Somba Opu, Kabupaten Gowa. Adapun waktu penelitian ini dilakukan selama 6 bulan yaitu pada Bulan Maret sampai Bulan Agustus 2018. Adapun variabel yang digunakan dalam penelitian ini yaitu penduduk, Pendidikan, aset yang dimiliki, pekerjaan dan tingkat penghasilan. Metode pengumpulan data dilakukan dengan wawancara, survei lapangan dan penggunaan kuesioner.

Populasi dari penelitian ini merupakan keseluruhan subyek penelitian yang memiliki kuantitas yang dapat memberikan data/informasi penelitian. Adapun populasi dalam peelitian ini adalah seluruh jumlah penduduk Kelurahan Samata yaitu 8.749 jiwa pada tahun 2018 (Kecamatan Somba Opu dalam angka tahun 2017). 
Setelah melihat dari jumlah populasi pada lokasi penelitian dengan jumlah KK sebanyak $1.749 \mathrm{KK}$, dan jumlah tersebut serta luasan kawasan yang sangat mudah dijangkau. Pada standar jumlah sampel rumah tangga ditemukan bahwa jumlah penduduk pada Kelurahan Samata $<50.000$ jadi minimal sampel yang akan disebar pada lokasi penelitian sebanyak 10\% jadi jumlah sampel pada Kelurahan Samata yaitu 10\%/ 1.749 maka hasilnya adalah $175 \mathrm{KK}$.

Analisis yang digunakan mencakup-Analisis Superimpones, yaitu proses tumpang susun antara dua atau lebih peta tematik untuk menghasilkan peta atau tematik kombinasi baru dengan menggunakan persamaan yang sesuai, analisis ini akan memberikan gambaran porsi perubahan lahan yang terjadi. Dengan melakukan tumpeng susun peta maka diharapkan akan menghasilkan suatu peta dengan gambaran yang jelas seberapa besar pengaruh segresi ruang. Selanjutnya-Analisis Uji Korelasi, analisis ini merupakan salah satu cara untuk mengkaji keterkaitan antara faktor yang berpengaruh antara koefisien korelasi (r). Dimana analisis ini digunakan untuk menentukan korelasi antara variabel tidak bebas dengan variabel. Variabel yang digunakan yaitu: $\mathrm{X}=$ Variabel bebas (sosial ekonomi masyarakat) dengan variabel yang digunakan yaitu: $\mathrm{X} 1$ = tingkat Pendidikan, $\mathrm{X} 2$ = tingkat kepemilikan bangunan, $\mathrm{X} 3$ = pendapat masyarakat, $\mathrm{X} 4$ = tingkat pekerjaan dan X5 = tingkat penghasilan. Dengan asumsi jika:

- $\quad r=$ mendekati harga 0 , hubungan antara kedua perubah sangat lemah atau tidak terdapat hubungan sama sekali

- $r=1$ atau mendekati 1 , korelasi antara kedua perubah dikatakan positif dan sangat kuat

- $\quad r=-1$ atau mendekati -1 , korelasi antara kedua perubah sangat kuat dan negative (Sugiyono, 2005).

\section{HASIL DAN PEMBAHASAN}

Kondisi umum lokasi penelitian menggambarkan lokasi yang terdampak dari perkembangan perkotaan di Kota Makassar. Lokasi penelitian terletak di Kelurahan Samata yang merupakan salah satu kelurahan dari 14 wilayah kelurahan Kecamatan Somba Opu Kabupaten Gowa. Perkembang Kota Makassar yang makin pesat, mendorong munculnya wilayah penyangga baru di wilayah sekitarnya, termasuk di Kelurahan Samata. Secara umum letak administrasi lokasi berbatasan pada sebelah utara 
berbatasan dengan Kota Makassar, sebelah selatan berbatasan dengan Kecamatan Bontomarannu, sebelah timur berbatasan dengan Kelurahan Romang Polong dan sebelah barat berbatasan dengan Kelurahan Paccinongan.

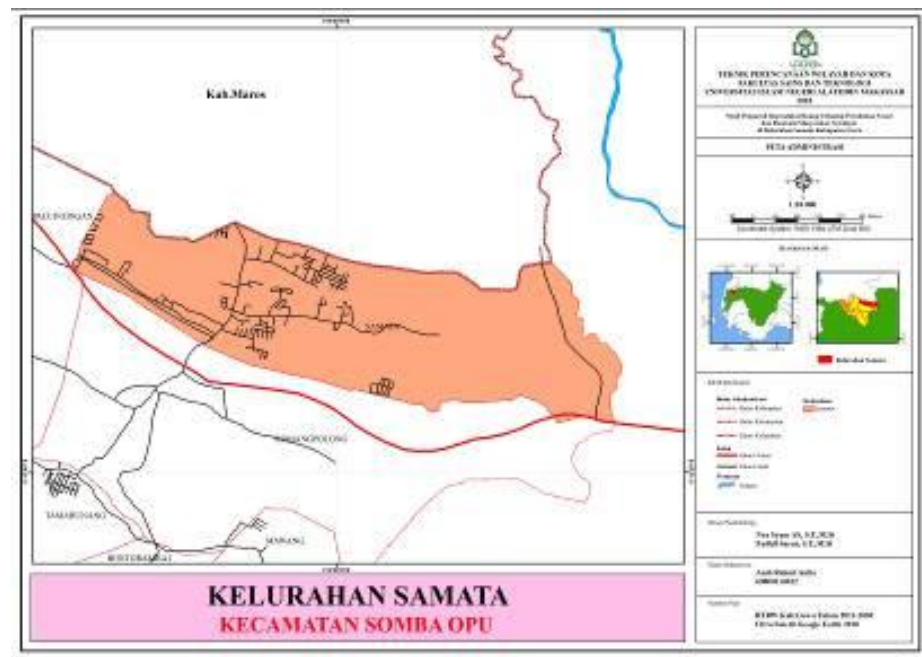

Gambar 1. Peta Kelurahan Samata Sumber : survei lapangan

Luas Wilayah Kelurahan Samata $\pm, 1,44 \mathrm{~km}^{2}$ dari luas total wilayah Kecamatan Somba Opu, yakni 28,09 $\mathrm{km}^{2}$. Secara administrasi Kabupaten Gowa terdiri dari 2 lingkungan dengan jumlah 8 RW dan 27 RT. Kelurahan Samata merupakan daerah daratan dengan ketinggian 43 mdpl. Jumlah pertumbuhan penduduk di Kelurahan Samata cenderung meningkat dimana pertumbuhan penduduk cenderung mengalami peningkatan setiap tahunnya. Pertambahan penduduk yang tertinggi terjadi pada tahun 2013 ke 2014 dengan pertambahan 750 jiwa sedangkan pertambahan penduduk yang paling rendah terjadi pada tahun 2014 ke 2013 dengan jumlah pertambahan 223 jiwa.

Berdasarkan karakteristik responden yang digunakan pada penelitian ini, diperoleh bahwa dari 175 responden yang memiliki Tingkat Usia terendah ialah berusia 51-60 sebanyak 39 jiwa (22\%), dan Tingkat Usia tertinggi ialah 31-40 sebanyak 58 jiwa (33\%). Sedangkan berdasarkan jenis kelamin responden ialah perempuan sebanyak 98 jiwa (56\%), sedangankan laki-laki sebanyak 77 jiwa (44\%). Tingkat Pendidikan terendalah ialah tamat SD sebanyak 33 jiwa (19\%), dan tingkat Pendidikan terbesar ialah SLTA sebanyak 36 jiwa (21\%). Berdasarkan status kepemilikan tanah dilokasi penelitian, ialah Tanah Milik Sendiri 151 jiwa (86\%), dan responden yang Kontrak 24 jiwa (14\%).

Proses reproduksi ruang yang terjadi di Kelurahan Samata ditandai dengan terjadinya perubahan penggunaan lahan dari fungsi non budidaya menjadi kawasan 
budidaya. Penggunaan lahan di Kelurahan Samata pada tahun 2018 yang terdiri atas penggunaan lahan permukiman, pertanian basah, sawah, kebun campuran, semak belukar, lahan kosong. Berdasarkan hasil penelitian perubahan penggunaan lahan yang paling dominan yang ada di wilayah penelitian Kelurahan Samata dari tahun 2013-2018 yaitu pertanian lahan basah, permukiman, dan sawah. Untuk lebih jelasnya dapat dilihat pada tabel perubahan penggunaan lahan berikut.

Tabel 1. Perkembangan Penggunaan Lahan di Kelurahan Samata

\begin{tabular}{llll}
\hline Penggunaan Lahan & Tahun 2013 & Tahun 2017 & Perubahan \\
\hline Permukiman & 71.70 & 82.97 & 11.27 \\
Pertanian Lahan Basah & 140.44 & 139.71 & -0.73 \\
Sawah & 122.13 & 118.77 & -3.36 \\
Kebun Campuran & 3.21 & 3.21 & 0 \\
Semak Belukar & 7.75 & 7.75 & 0 \\
Lahan Kosong & 71.21 & 64.03 & -7.18 \\
\hline
\end{tabular}

Sumber : hasil overlay peta, tahun 2018

Pada tabel jumlah perubahan lahan pada tahun 2017 diatas dapat diketahui bahwa berdasarkan hasil overlay dengan melihat penggunaan lahan pada tahun 2013 untuk penggunaan lahan yang mengalami pertambahan yaitu jumlah lahan permukiman dengan mencapai luas perubahan 11.27 Ha. Dilihat dari pertambahan pada lahan permukiman ini disebabkan karena jumlah penduduk di Kelurahan Samata semakin meningkat.

Penerapan metode uji korelasi terhadap faktor yang mempengaruhi perubahan kondisi sosial ekonomi masyarakat setempat setelah reproduksi ruang dihitung berdasarkan 4 variabel yaitu tingkat Pendidikan, tingkat kepemilikan bangunan, pendapat masyarakat, tingkat pekerjaan dan tingkat penghasilan. Hasil rekaputulasi uji korelasi pada penelitian ini disajikan pada tabel berikut:

Tabel 2. Rekapitulasi pengaruh reproduksi ruang terhadap sosial ekonomi

\begin{tabular}{llllll}
\hline \multicolumn{1}{c}{ Variabel } & $\begin{array}{c}\text { Sangat Rendah } \\
(\mathrm{o}, 00-0,199\end{array}$ & $\begin{array}{c}\text { Rendah } \\
(\mathrm{o}, 200-0,399\end{array}$ & $\begin{array}{c}\text { Sedang } \\
(\mathrm{o}, 400-0,599\end{array}$ & $\begin{array}{c}\text { Kuat } \\
(\mathrm{o}, 600-0,799\end{array}$ & $\begin{array}{c}\text { Sangat Kuat } \\
(\mathrm{o}, 800-1,000)\end{array}$ \\
\hline Jumlah penduduk & - & - & - & - & 0,961 \\
Pendidikan & - & - & 0,482 & - & - \\
Kepemilikan tanah & - & - & - & 0.734 & - \\
Pekerjaan & - & - & - & 0,716 & - \\
Penghasilan & - & - & - & - & - \\
\hline
\end{tabular}

Sumber : hasil analisis, tahun 2018

Berdasarkan hasil rekapitulasi pengaruh reproduksi ruang dari aspek kondisi sosial dan ekonomi masyarakat berdasarkan dari beberapa variable dan hasil dari akumulasi nilai responden dari kuesioner maka dapat diktehaui bahwa faktor yang berpengaruh terhadap reproduksi ruang yaitu Kelurahan Samata adalah jumlah penduduk dengan 
nilai korelasi yaitu 0,961, pendidikan dengan nilai 0,482, kepemilikan tanah dengan nilai 0,734 , pekerjaan dengan nilai 0,716 dan penghasilan dengan nilai 0,476.

Perubahan guna lahan merupakan suatu hal yang menjadi dari perkembangan kota. Terkait dengan reproduksi ruang, perubahan penggunaan lahan yang terjadi adalah konversi lahan kegiatan pertanian yang berubah menjadi fungsi komersial. Untuk reproduksi ruang di Kelurahan Samata, konversi lahan banyak terjadi karena nilai lahan yang sangat tinggi dan kurang menguntungkan ketika hanya memanfaatkan sebagai fungsi kawasan pertanian. Berdasarkan hasil penelitian reproduksi ruang bahwa adanya pembangunan fasilitas perekonomian disepanjang jalan yang berdampak pada nilai lahan yang tinggi sehingga banyak masyarakat menjual lahan untuk dialih fungsikan menjadi kawasan permukiman dan perdagangan jasa yang bernilai ekonomis yang dapat digunkan untuk tujuan investasi, konversi lahan pertanian pada akhirnya memberikan dampak, baik terhadap masyarakat, aktifitas, maupun lingkungan.

Dalam reproduksi ruang di Kelurahan Samata, konversi lahan menyebabkan terjadinya transformasi pekerjaan masyarakat meningkatkan pendapatan secara ekonomis, dengan masuknya penduduk pendatang. Namun demikian, reproduksi ruang bedampak pada penurunan kondisi lingkungan akibat urbanisasi yang mengubah guna lahan yang saat ini lebih dominan untuk kegiatan permukiman. Proses reproduksi ruang di Kelurahan Samata juga berdampak pada dinamika sosial masyarakat berarti bahwa masyarakat selalu berkembang serta mengalami perubahan. Hal ini ditandai dengan perubahan pola kerja, tingkat sosialisasi dan beberapa factor lain.

Perubahan selalu akan ada dalam setiap kelompok sosial, baik mengalami secara lambat maupun secara cepat. Perubahan sosial juga sebagai suatu proses perubahan struktur sistem di dalam masyarakat. Namun demikian, reproduksi ruang berdampak pada interaksi sosial masyarakat di Kelurahan Samata yang dimana sebelum terjadinya reproduksi ruang interaksi masyrakat masih kurang dikarenakan kerawanan lingkungan sedangkan setelah terjadinya reproduksi ruang interaksi masyarakat lebih membaik dikarenakan kondisi lingkungan yang mulai berkembang.

Reproduksi ruang mampu memacu ekonomi perkotaan karena adanya perbedaan ukuran kota yang mendorong kota untuk saling berbagi sumber daya spesifik yang dimiliki termasuk yang didalamnya infrastruktur dan berbagai fasilitas publik, ini menujukkan bahwa ada saling ketergantungan antar kawasan. Hal ini meningkatkan 
frekuensi mobilitas masyarakat akibat adanya ketergantungan kawasan di sekitar Kelurahan Samata.

\section{SIMPULAN}

Berdasarkan hasil penelitian reproduksi ruang bahwa adanya pembangunan fasilitas perekonomian dan permukiman yang berdampak pada nilai lahan yang tinggi sehingga banyak masyarakat menjual lahan untuk dialih fungsikan menjadi kawasan permukiman dan perdagangan jasa yang bernilai ekonomis. Untuk perkembangan penggunaan lahan yang banyak meningkat berdasarkan hasil overlay mulai 2013 sampai dengan 2018 yaitu jumlah lahan permukiman dengan mencapai luas perubahan 11.27 Ha. Dilihat dari pertambahan pada lahan permukiman ini disebabkan karena jumlah penduduk di Kelurahan Samata semakin meningkat. Berdasarkan hasil uji korelasi, Pengaruh perkembangan Kelurahan Samata memberikan pengaruh besar terhadap pertambahan penduduk dengan nilai korelasi yaitu 0,961, pendidikan dengan nilai 0,482, kepemilikan tanah dengan nilai 0,734 , pekerjaan dengan nilai 0,716 dan penghasilan dengan nilai 0,476. Jadi pengaruh reproduksi ruang di Kelurahan Samata memberikan dampak di Kelurahan Samata Kabupaten Gowa.

\section{DAFTAR PUSTAKA}

AS N., 2013, Struktur Tata Ruang Wilayah dan Kota, Alauddin University Press, Makassar.

BPS Kabupaten Gowa Online: Kecamatan Somba Opu Dalam Angka Tahun 2017.

Dingingrat, R.A. Segreagasi Spasial Perumahan Skala Besar: Studi Kasus Kota Harapan Baru Bekasi. Jurnal Perencanaan Wilayah dan Kota, Volume 26 No 2. Institut Teknologi Bandung

Eckert. (1990). Property Apparaisal and Assesment Administratiom. Chicago Ilinois: IAAO.

Eisenring, T. S. (2017). Sosiologi Perkotaan. Makassar: Fahmis Pustaka.

Halim, D. K. (2008). Psikologi Lingkungan Perkotaan. Jakarta: Bumi Aksara.

Masrukan, $\quad$ Definisi dan Konsep Perkembangan Kota http://perencanaankota.blogspot.com/2011/11/definisi-dan-konsep-perkembangankota.html diakses pada tanggal 27 Februari 2018

Handayani, R. (2014). Pembangunan Masyarakat Pedesaan. Makassar: Alauddin Univesity Press.

Pamungkas, A. S. (2016). Produksi Ruang dan Reolusi Kaum Urban Menurut Henri Lafebvre. Lembar Kebudayaan Indoprogress, LKIP Edisi 31.

Penaung Umum Al-Mujamma'., 1971, Al-Qur'an dan Terjemahnya, Departemen Agama RI, Jakarta.

Paturusi, S. A. (2016). Segregasi Ruang Sosial Antara Pendatang dengan Penduduk Lokal. Jurnal Kajian Bali , 57-78.

Syarbaini, Syahrial dan Rusdiyanta. (2009). Dasar-Dasar Sosiologi. Yogyakarta: Graha Ilmu

Sujarto, D (1995) Perencanaan Kota Baru. Bandung: Penerbit ITB

Sutawijaya, A. (2004). Analisis Faktor Faktor Yang Memepengaruhi Nilai Tanah Sebagai Dasar Penlilaian Nilai Jual Objek Pajak (Njop) Pbb Di Kota Semarang. Jurnal Ekonomi Pembangunan.

Sihotang, R. P. (2017). Pola Segregasi Permukiman Masyarakat Pekanbaru. 1-15. Undang-undang Republik Idonesia Nomor 26 Tahnun 2006 Tentang Penataan Ruang.

Widodo, T. H. (2016). Segregasi Penduduk Di Desa Suka Maju Kecamatan Ulubelu Kabupaten Tenggamus. 20-68.

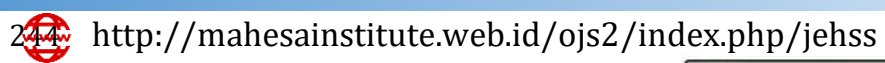

